\title{
A review of the influence of beaver Castor fiber on amphibian assemblages in the floodplains of European temperate streams and rivers
}

\author{
Lutz Dalbeck ${ }^{1}$, Monika Hachtel² \& Róisín Campbell-Palmer ${ }^{3}$ \\ ${ }^{1}$ Biological Institute of Nature Conservation Düren, Zerkaller Straße 5, 52385 Nideggen, Germany \\ 2 Biological Institute of Nature Conservation Bonn, Auf dem Dransdorfer Berg 76, 53121 Bonn, Germany \\ ${ }^{3}$ Edinburgh, EH7 6NH, UK
}

\begin{abstract}
Once widespread throughout Eurasia and hunted nearly to extinction, the Eurasian beaver Castor fiber has returned to large parts of its former range, largely through active conservation measures. Beavers can substantially alter small, low order streams and their floodplains through dam construction, burrowing activities and tree felling. Therefore, it is presumed they can significantly influence amphibian distributions, species richness and numbers. We undertook a literature review to compare the available data addressing the effects of beaver dams on amphibians in streams of central temperate and boreal Europe. All 19 amphibian species occurring in the study region were found in beaver ponds, despite their distinctly different habitat requirements. Amphibian species acting as pioneers / early colonisers were under-represented in beaver ponds compared to typical forest species. Open country and ubiquitous species showed intermediate patterns. Beaver ponds in headwater streams often supported the entire spectrum of species occurring in the surrounding landscape, and species numbers in beaver modified headwater streams were comparable to those in floodplains of larger natural rivers. In small headwater streams, beavers tended to be the primary providers of essential habitat for amphibians. In contrast, beaver ponds in the floodplains of larger rivers appeared to have less effect and supported lower average species numbers compared to beaver ponds in headwater streams. We propose that beavers and their habitat creating activities are pivotal determinants of amphibian species richness in the headwater streams, which account for $60-80 \%$ of the water bodies in catchment areas in temperate Europe. By creating habitat for endangered amphibian species, beavers and their ability to modify habitats offer extensive opportunities to implement many aspects of the European Water Framework Directive across the continent and to restore amphibian habitats, contributing to their long-term conservation.
\end{abstract}

Keywords: natural floodplains, wetland restoration, amphibian habitat, ecosystem engineers, species richness, headwater stream, Anura, Urodela

\section{INTRODUCTION}

A mphibians are a highly endangered vertebrate class in Europe (Temple \& Cox, 2009) and all European species are protected by the European Union Habitats Directive 92/43/EEC. Small headwater, 1st to 3rd order streams account for $60-80 \%$ of the streams of a catchment area (Benda et al., 2005; Spänhoff et al., 2012; Ulevičius et al., 2011), and their associated floodplains are considered to support naturally low amphibian species richness across large areas of northern and temperate Europe (Günther, 1996; Thiesmeier, 2004; Weddeling \& Willigalla, 2011). In south-west Europe (west of the Pyrenees) and in the European Mediterranean regions, several amphibian species, including Salamandrina terdigitata, Chioglossa lusitanica, Rana graeca, $R$. italica and $R$. iberica occur in flowing waters (Nöllert \& Nöllert, 1992), whilst their numbers are very limited in the rest of Europe. In the temperate regions east of the Pyrenees there is only one amphibian species, the fire salamander Salamandra salamandra, which tends to inhabit small headwater streams, breeding in fish-free streams but also in associated floodplain ponds (Thiesmeier \& Günther, 1996). Additional species are more commonly found in adjacent floodplain ponds, inlcuding palmate and alpine newts Lissotriton helveticus and Ichthyosaura alpestris, the common frog Rana temporaria (Weddeling \& Willigalla, 2011) and to a lesser extent the midwife toad Alytes obstetricans (Borgula \& Zumbach, 2003). Outside of this area, there are no amphibian species in eastern and northern Europe that prefer to reproduce in flowing waters. Compared to floodplains of larger lowland and gravel-bed rivers, the floodplains of these headwater streams have fewer ponds, lower hydrodynamics and unfavourable thermal conditions due to associated closedcanopy riparian forests (Skelly \& Freidenburg, 2000). 
Alternatively, natural floodplains of larger and gravelbed rivers naturally are highly dynamic environments in which water fluctuations and sedimentation act as the primary agents of disturbance (Tockner et al., 2006). They can be considered as hot spots for biodiversity, including amphibian species (Naiman \& Decamps, 1997; Tockner et al., 2006) and hence have significant conservation value (Ward et al., 1999; Klaus et al., 2001). In temperate Europe, the few remaining natural floodplains of larger lowland rivers such as the Rhone or the Danube or gravel-bed rivers as the Tagliamento are species rich in amphibians (Tockner et al., 2006; Pintar, 2001; Kuhn et al., 2001) because they offer a high diversity of varying types of lentic breeding waters and adjacent terrestrial habitat. In these natural floodplains, most, or even all, amphibian species in the respective larger landscapes are represented and able to reproduce. However, these areas are also highly productive to humans, often making them one of the most modified ecosystems worldwide (Tockner et al., 2006; Harvolk et al., 2014). Within Europe, the majority ( $>90 \%$ ) of larger rivers and streams are regulated by human activities and disconnected from their floodplains. These modern floodplains are therefore functionally extinct (Tockner et al., 2006). The importance of the ecological services provided by natural watercourses have been recognised through the European Water Framework Directive 2000/60/EG (WFD) which requires all EU member states to restore all flowing waters to 'good ecological status' (Törnblom et al., 2011).

The Eurasian beaver Castor fiber, formerly widely distributed in freshwater systems across Europe between North Cape and Gibraltar, was almost completely eradicated globally in the nineteenth century through over-hunting. Strict protection and reintroduction programmes have since seen its restoration across much of its native range (Halley et al., 2012). This species can shape landscapes, particularly through its dam building, burrowing and tree felling activities (Rosell et al., 2005). Such activities substantially affect terrestrial as well as aquatic habitat parameters that are crucial for the specific requirements of European amphibians (Günther, 1996; Denoël \& Ficetola, 2008; Indermaur et al., 2009). This is especially evident when beavers impound low order streams, changing free flowing streams into a series of ponds that inundate floodplains (Naiman et al., 1986; Stevens et al., 2007). This leads to changes in the physical structure of the streams and their associated floodplains, creating sections with lentic conditions and shallow water. By felling and drowning trees, beavers cause the shallow sections of these water bodies to become significantly warmer as formerly shaded areas experience increased light levels (Skelly \& Freidenburg, 2000). Increased insolation leads to the development of emerged and submersed vegetation (Ray et al., 2001). Adjacent terrestrial habitats are also affected, as the browsing activities of beavers reduces vegetation height in the immediate vicinity of freshwater bodies (Naiman et al., 1988; Rosell et al., 2005).

Beaver ponds tend to be located in the smaller flowing waters of the respective water systems, which are populated by characteristic fish species assemblages, depending on the water type and catchment area. In Europe, salmonids dominate in headwater streams, and various cyprinids and gasterosteids in lowland streams (Melcher et al., 2007). Accordingly, in contrast to many floodplain ponds of larger gravel-bed rivers (Tockner et al., 2006), fish regularly occur in ponds created by beavers (Keast \& Fox, 1990; Hägglund \& Sjöberg, 1999; Halley \& Lamberg, 2001; Sigourney et al., 2006). Since fish, as dominating predators of eggs, larvae and adults, can exclude amphibians from colonising a water body (Bronmark \& Edenhamn, 1994; Hecnar \& M'Closkey, 1997; Leu et al., 2009), it is unclear to what extent amphibians can benefit from beaver ponds in Europe. For example, in North Rhine-Westphalia, Germany, where 17 of the 19 amphibian species in the area considered here occur, only one species, the common toad Bufo bufo, prefers fish-populated waters, while 14 species clearly avoid waters occupied by fish (Weddeling \& Willigalla, 2011). Since beavers strongly prefer waters surrounded by deciduous woodland (Pinto et al., 2009), we expect that forest living amphibian species will primarily benefit from beaver ponds, unless they are subjected to heavy fish predation. This particularly applies to midwife toads Alytes obstetricans, yellow-bellied toads Bombina variegata and fire salamanders (Weddeling \& Willigalla, 2011). Therefore, we expect species that rely on open upland terrestrial habitats to be generally under-represented in beaver ponds. This is especially true for species that require terrestrial habitats with little vegetation and bare substrate and spawning waters with limited predators.

The effect of beaver impoundments on amphibian assemblages in Europe appears an under-investigated research area. Janiszewski et al. (2014) mentioned only two studies concerning the effects of beavers on European amphibian assemblages. Rosell et al. (2005) only cited studies from North America where the effect of beaver impoundments on amphibians is well investigated (e.g. Metts et al., 2001; Wright et al., 2002; Cunningham et al., 2007; Stevens et al., 2007). However, the amphibian fauna of North America is rich in stream dwelling (urodelan) species (Petranka, 1998), which is a notable difference compared to the European herpetofauna, and therefore patterns cannot be readily transferred between continents.

There are, in fact, more studies on amphibians in beaver modified waters in Europe than quoted in the aforementioned review articles. The results of these studies do not support the general belief that low numbers of amphibian species inhabit natural headwater streams and their floodplains (e.g. Dalbeck et al., 2007). Thus, the general role of beaver-modified landscapes for amphibians in Europe and their conservation needs to be reassessed. We therefore investigated the impact of beaver activities on European amphibian habitats. Through a systematic review, as well as using existing studies and our own data from amphibian populations occurring in temperate and boreal Eurasian beaver habitats, we aim to address the following questions:

1. Which amphibian species benefit from beaver activity 
and is it possible to assign these species to recognised amphibian assemblages? What do we know about the effects of the beaver on the amphibian abundance?

2. Do the effects of beaver activity on amphibian assemblages differ along various reaches within a river corridor (i.e. headwater streams versus floodplains of higher-order stream sections in lower reaches of systems)?

3. How significant is beaver activity for amphibian species richness in the floodplains of small streams compared to natural floodplains of larger lowland and gravel-bed rivers, which are hotspots of amphibian diversity where floods are the dominant agent of disturbance, shaping abiotic and biotic patterns?

\section{METHODS}

\section{Literature review}

A literature review was undertaken on studies that investigated the effects of beaver on both ecosystems in Europe and amphibian biodiversity and abundance, including articles in both reviewed and non-reviewed scientific journals. Google Scholar, Web of Knowledge and Research Gate were searched using the following key words: beaver, Castor, fiber, canadensis (as the species is established in Finland and parts of NW Russia), Amphibia, Anura, Urodela, Caudata. We further personally consulted beaver specialists who have extensive literature databases (Volker Zahner, Karl A. Nitsche) to find literature on the abovementioned keywords that were not covered by the search engines used. We also contacted a range of amphibian specialists via email or personally about any unpublished degree theses or project reports dealing with the subject of beavers and amphibians (Russia: Ivan Bashinskiy, Switzerland: Kurt Grossenbacher, Germany: K. A. Nitsche, V. Zahner, Denmark: Morten Elmeros, France: Rémi Duguet). If the study methods were not clearly described, we contacted the authors of both published and unpublished studies by email or in person to obtain information on the methodological approach used, in particular for the recording of urodelan species. To compare the effects of beavers across different stream sections, we categorised rivers with beaver impoundments as follows: (1) beaver ponds in small upland and lowland headwater streams of 1 st to 3 rd order and (2) floodplains of larger rivers of $\geq 4$ th order, where beavers are able to create dams on the main stem of the river or build dams on tributaries and other smaller running waters within the floodplain.

\section{Inclusion protocol}

The studies concerning amphibians in beaver-created landscapes differed markedly with respect to extent, methodological approach and reference area. Content ranged from anecdotal mention of amphibians to focused studies on specific species. Urodelan species, in particular, were obviously insufficiently surveyed in some of the studies because methods used were not adequate for reliable detection of this group. Therefore, to compare species numbers we only included studies meeting a minimum methodical effort, specifically if systematic surveys were conducted during the most appropriate time of the year for the detection of expected species. In areas where urodelan species were absent, such standard surveys are typically adequate for characterising the amphibian assemblage. For areas in which urodelan species are likely to be present, further survey methods are necessary, e.g. night surveys using torch lights or, even better, the use of funnel traps. Studies that did not meet the above minimum requirements were not included. For anurans, we defined a survey for spawn, adult animals and calling individuals as sufficient.

In total, 10 of the 21 studies (five in headwater streams and five in the floodplains of larger rivers) meet our requirements for a systematic survey (Table 1 ). The methodological approaches of the studies included in our review are presented in Table 2.

\section{Amphibian assemblages}

Amphibian species of temperate Europe tend to occur in repeatable, non-random assemblages (e.g. Tockner et al., 2006). Therefore, we assigned the amphibian species found at beaver sites to four ecological assemblages using information on their habitat requirements in central and northern Europe as given in Nöllert \& Nöllert (1992), Gasc et al. (2004) and Denoël \& Ficetola (2008). These were as follows:

(1) Pioneer species: three species that depend on a high level of natural or artificial disturbance and prefer fully sunlit, often ephemeral and therefore predator-poor, breeding pools (yellow bellied toad Bombina variegata, green toad Bufotes viridis, natterjack toad Epidalea calamita). The latter two species are associated with terrestrial habitats of early successional stages (typically having undergone previous disturbance) with sparse vegetation.

(2) Open country species: five species, mainly inhabiting open landscapes or open clearings in forest areas which are mainly anthropogenic in origin. These species often require breeding sites with high summer water temperatures (crested newt Triturus cristatus, smooth newt Lissotriton vulgaris, fire bellied toad Bombina bombina, tree frog Hyla arborea, common spadefood Pelobates fuscus). They often reproduce in water bodies with dense submersed vegetation. Unlike the pioneer species, these species do not depend on temporary pools and barren upland terrestrial habitats.

(3) Forest species: six species mainly restricted to deciduous or coniferous forest, requiring or tolerating shaded forest waters for reproduction (fire salamander, alpine, palmate and carpathian newt L. montandoni, agile frog Rana dalmatina, common toad).

(4) Ubiquitous species: four species, using a wide range of habitats both forest and open land (common frog, moor frog $R$. arvalis, marsh and pool frogs Pelophylax ridibundus, $P$. lessonae, including the hybrid forms $P$. "esculentus" (hereinafter referred to as "water frogs") and one species that does not fit into any of the first three categories (midwife toad Alytes obstetricans). 
Table 1. Data on the beaver ponds of the respective regions. No.: Corresponds to the number on the map (Fig. 1). Age: age of the beaver ponds in years.

\begin{tabular}{lllllll}
\hline No & Country & Region & Age & Landscape Type & Stream Type & Location of Beaver Dams \\
\hline 1 & Switzerland & Aare Valley & $<5$ & Pre-alpine & River / floodplain & Alluvial water in floodplain \\
2 & Germany & Isar Valley & $5-20$ & Lowland & River / floodplain & Alluvial water in floodplain \\
3 & Germany & Middle Franconia & $5-20$ & Lowland & Low order stream & Main channel \\
$4 a$ & Germany & Eifel & $>20$ & Low Mountain & Low order stream & Main channel \\
$4 \mathrm{~b}$ & Germany & Rur Valley & $<5$ & Lowland & River / floodplain & Alluvial water in floodplain \\
5 & Denmark & Klosterheden & $5-20$ & Lowland & Low order stream & Main channel \\
6 & Lithuania & Lithuania & $>20$ & Lowland & Low order stream & Main channel \\
7 & Russia & Gorelka River & $>20$ & Lowland & River & Main channel \\
8 & Russia & Tadenka River & $>20$ & Lowland & River & Main channel \\
9 & Poland & Carpathians & $5-20$ & Mountain & Low order stream & Main channel \\
\hline
\end{tabular}

Table 2. Classification of amphibian studies in beaver ponds across Europe. Effort: $1=$ Systematic surveys for anuran and urodelan species including funnel traps. 2 = Observations of calling individuals during the day in the main seasons of activity. Species no = average number of species per single pond \pm standard deviation. $\Sigma$ species: total number of species encountered breeding in beaver ponds during the study. In parentheses: total number of species, including those lacking evidence of reproduction. Regional species no: Total number of amphibian species known for the study region. Scale: territory: number of beaver territories each containing several ponds, pond: single beaver pond.

\begin{tabular}{|c|c|c|c|c|c|c|c|}
\hline Region & Focus & Effort & Species no & $\sum$ species & $\begin{array}{c}\text { Regional } \\
\text { species no }\end{array}$ & Scale & n \\
\hline \multicolumn{8}{|c|}{ Small streams and headwaters ( $1^{\text {st }}$ to $3^{\text {rd }}$ order) } \\
\hline Eifel, DE ${ }^{1)}$ & local & 1 & $4.8 \pm 1.2$ & 9 & 9 & pond & 22 \\
\hline Franconia, DE ${ }^{2)}$ & regional & 2 & ? & 9 & 9 & territory & 10 \\
\hline Klosterheden, DK ${ }^{3)}$ & local & $2^{\text {a) }}$ & $<3$ & 3 & 3 & pond & $?$ \\
\hline Lithuania ${ }^{4)}$ & country & 2 & $?$ & $7(8)$ & 11 & territory & 40 \\
\hline Bieszczady NP, PL $^{5}$ & regional & $1^{\mathrm{b})}$ & $3.8 \pm 0.7$ & 5 & 5 & territory & 6 \\
\hline \multicolumn{8}{|c|}{ Floodplains of rivers ( $\geq 4^{\text {th }}$ Order) } \\
\hline Gorelka, Novgorod, RU 6) & local & 1 & $<3$ & $3(4)$ & 6 & territory & 33 \\
\hline Tadenka, Moskow, RU 7) & local & 1 & $<3$ & $4(6)$ & 9 & territory & 46 \\
\hline Aare, $\mathrm{CH}^{8)}$ & local & 1 & $1.0 \pm 1.3$ & 4 & 10 & pond & 16 \\
\hline Isar, DE ${ }^{9)}$ & local & 1 & $1.1 \pm 1.0$ & 4 & 8 & pond & 22 \\
\hline Rur, DE ${ }^{10)}$ & local & 1 & $1.0 \pm 1.4$ & 3 & 6 & pond & 2 \\
\hline
\end{tabular}

a) Urodelan species are absent from the study area (Elmeros pers. comm.). ${ }^{\text {b) }}$ Extensive search also for urodelan species although without funnel traps (Hędrzak pers. comm.). Sources: ${ }^{1)}$ : Dalbeck \& Weinberg (2009); ${ }^{2)}$ : Meßlinger (2012), pers. comm; ${ }^{3)}$ : Elmeros et al. (2003, 2007, 2009); Damm (2009); ${ }^{4)}$ : Balčiauskas et al. (2001) nationwide; ${ }^{5)}$ : Derwich et al. (2007); ${ }^{6)}+{ }^{7)}$ : Bashinskiy (2008, 2012, 2014), pers. comm.; 8): Lüscher \& Rutishauser (2012), pers. comm.; 9): Junginger (1997); ${ }^{10)}$ : Dalbeck (unpublished data). CH: Switzerland; DE: Germany; DK: Denmark; PL: Poland; RU: Russia.

\section{RESULTS}

\section{Available data}

To date, studies on amphibians in beaver-impounded streams in Europe are available from temperate and southern boreal Europe (Gasc et al., 2004) ranging from humid and mild sub-oceanic conditions (Denmark, Western Germany) to a continental climate in NW Russia (Fig. 1). Data came from 10 regions distributed over six countries between a latitude of $46^{\circ} 53^{\prime} \mathrm{N}$ and $58^{\circ}$ $\mathrm{N}$ and a longitude of $6^{\circ} 23^{\prime}$ and $37^{\circ} 32^{\prime} \mathrm{W}$ (Fig. 1, Table 1). One systematic study from southern boreal Finland investigated beaver-flooded lakes and not impounded streams (Vehkaoja \& Nummi, 2015) and therefore was not considered here. To our knowledge there are no studies from Mediterranean countries and the oceanic west of Europe.

The physiography and morphology of streams and their floodplains with beaver ponds included: (1) small headwater streams only a few meters below the source in upland areas with discharges of $<1 \mathrm{l} / \mathrm{sec}$ and the following larger sections of 2 nd and 3rd order, Eifel region (DE), (2) 2nd and 3rd order streams in lowland areas, Frankonia (DE), Klosterheden (DK), Lithuania, (3) 1st to 3rd order streams in eastern Carpathians mountain areas at $670 \mathrm{~m}$ to $800 \mathrm{~m}$ a.s.l. (PL), (4) groundwater-fed channels in the pre- alpine zone, Aare Valley $(\mathrm{CH}),(5)$ medium sized (15 $\mathrm{m}$ wide) eastern European lowland rivers, NovgorodProvince (RU), and (6) beaver ponds in the floodplains of larger rivers, Isar, Rur Valley (DE, Table 1). The slope 


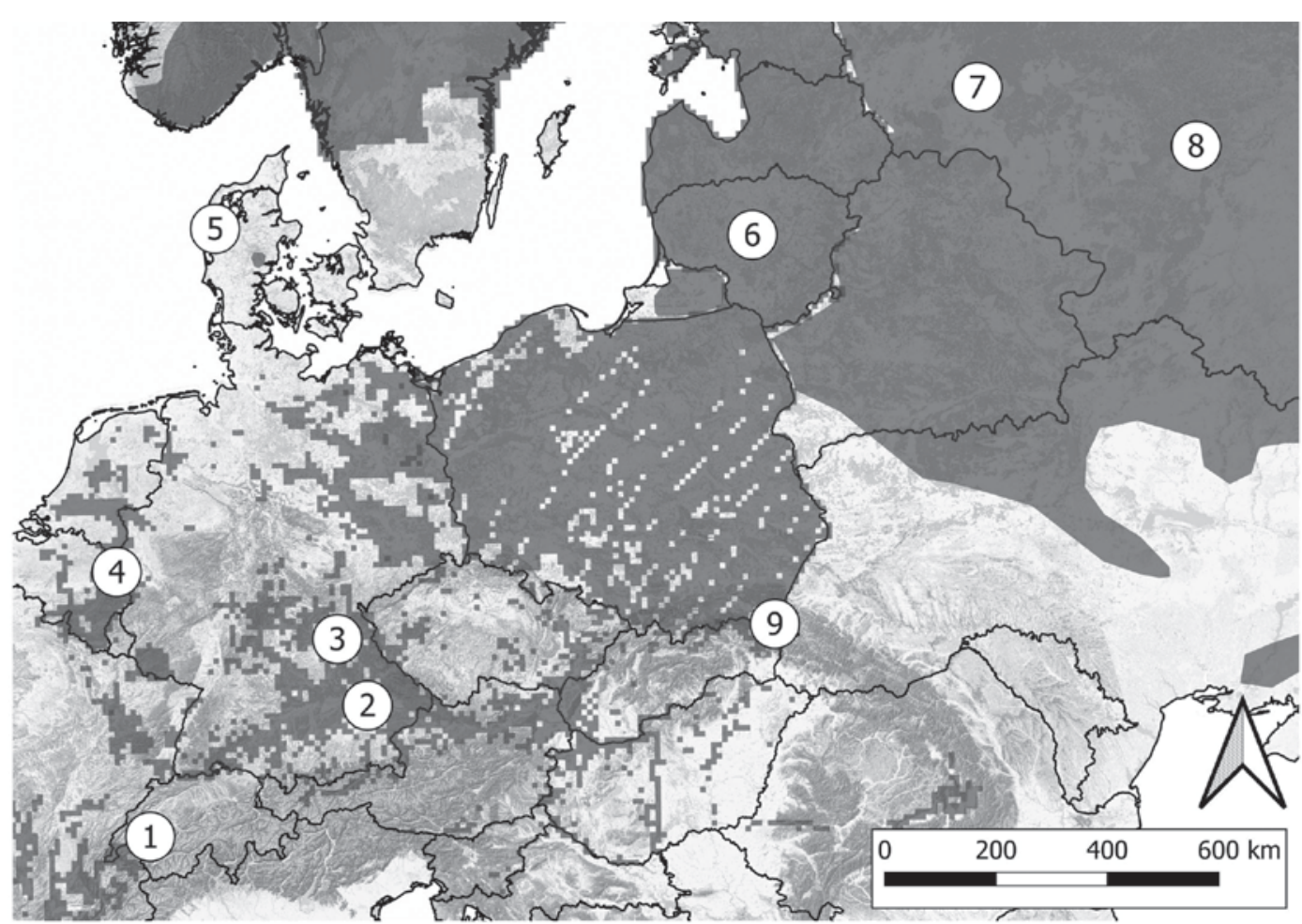

Figure 1. Distribution of the study areas: 1: Aare Valley, $\mathrm{CH}$; 2: Isar valley, DE; 3: Franconia, DE, 4: Eifel area and Rur valley, DE; 5: Klosterheden, DK; 6: Lithuania, LT; 7: Gorelka, Novgorod, RU; 8: Tadenka, Moskow, RU; 9: Bieszczady National Park, PL. Dark shaded: Distribution of Castor fiber (Halley et al., 2012).

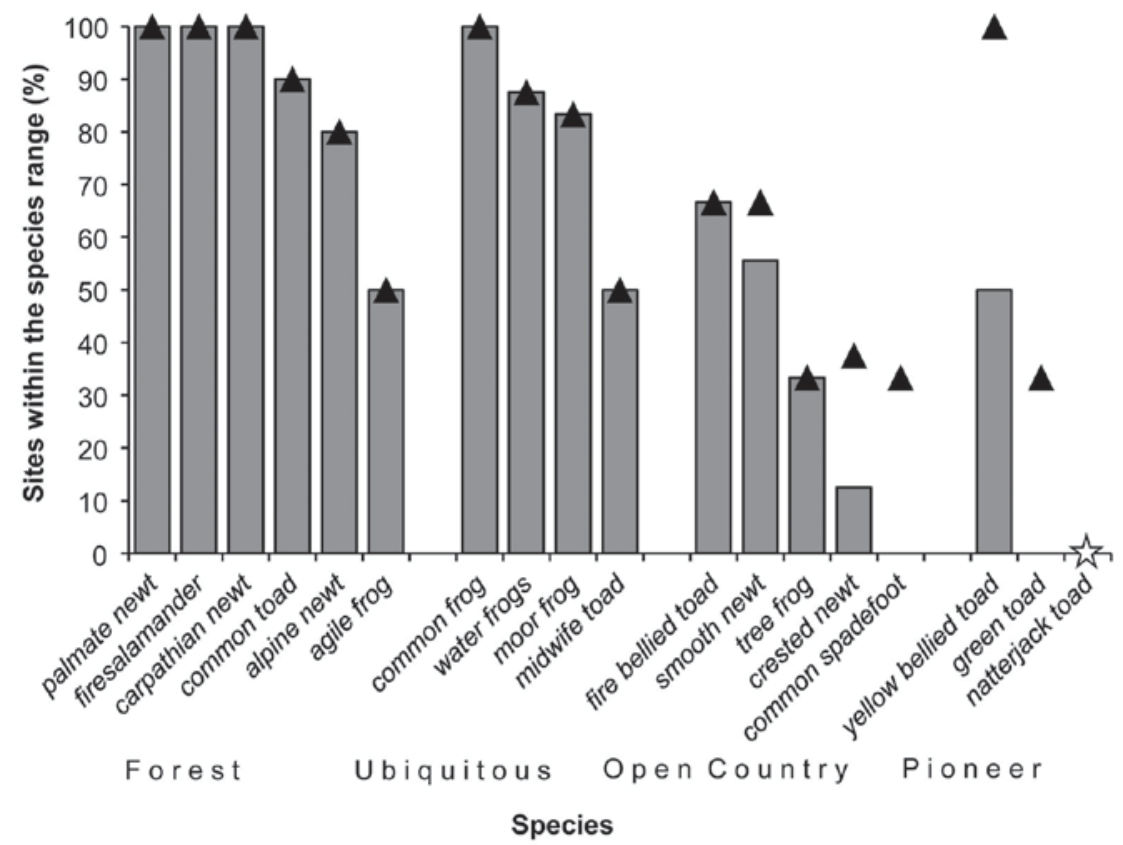

Figure 2. Distribution of amphibians in beaver ponds across 10 studies in temperate and boreal Europe. For each species, only results from studies within the range of a species are presented, i.e. the species was potentially able to colonise beaver ponds (for data and n see Table 2). Bars: percentage of studies where reproduction of the given species was documented or probable; triangles: all records including observations of single (probably non-reproducing) specimens; Star: descriptive data from the literature lacking further information, i.e. without proven reproduction; Epidalea calamita (Gschwend, 2015).

of the streams varied from $<1 \%$ to $>6 \%$; the width of the floodplains ranged from $0 \mathrm{~m}$ to $>500 \mathrm{~m}$. Thus, the size of the beaver ponds created by dams varied considerably between $<4 \mathrm{~m}$ and $>60 \mathrm{~m}$ in width, but general characteristics of the ponds can be considered as similar (Rosell et al., 2005). The age of the beaver ponds studied ranged from a few years (Aare Valley, $\mathrm{CH}$ ) up to 30 years (Lithuania; Ulevičius et al., 2009).

\section{Amphibian species of beaver ponds}

In total, 19 amphibian species (13 anuran and six urodelan species) were detected in beaver ponds (Fig. 2, 
Table 3. Distribution of amphibian species found in European beaver ponds.

Amphibian assemblages: $\mathrm{U}=$ ubiquitous species: $\mathrm{F}=$ forest species, $\mathrm{O}=$ open country species, $\mathrm{P}=$ pioneer species.

$X$ : species documented in beaver ponds; -: species potentially occurs in the region but was not found in beaver ponds; blank: Species is absent the region; A) Urodelan species. FS: fire salamander, AN: alpine newt, CN: crested newt, CaN: carpathian newt, SN: smooth newt, PN: palmate newt. B) Anuran species. MT: midwife toad, FT: fire-bellied toad, YT: yellow-bellied toad, CS: common spadefoot, CT: common toad, GT: green toad, NT: natterjack toad. TF: tree frog, WF: water frog, incl. hybrids, CF: common frog, AF: agile frog, MF: moor frog. Reproduction: +: proved or probable, -: not proved, ?: no information.

\begin{tabular}{lcccccc}
\hline A) Urodela & FS & AN & CN & CaN & SN & PN \\
\hline Community & F & F & O & F & O & F \\
\hline Eifel, DE & & Small streams and headwaters (1 ${ }^{\text {st }}$ to $3^{\text {rd }}$ order) & & \\
Franconia, DE & $\mathrm{X}$ & $\mathrm{X}$ & & $\mathrm{X}$ & $\mathrm{X}$ \\
Klosterheden, DK & $\mathrm{X}$ & $\mathrm{X}$ & & & \\
Lituania, LT & & & $\mathrm{X}$ & & \\
Bieszczady NP, PL & & $\mathrm{X}$ & $\mathrm{X}$ & $\mathrm{X}$ & \\
\hline
\end{tabular}

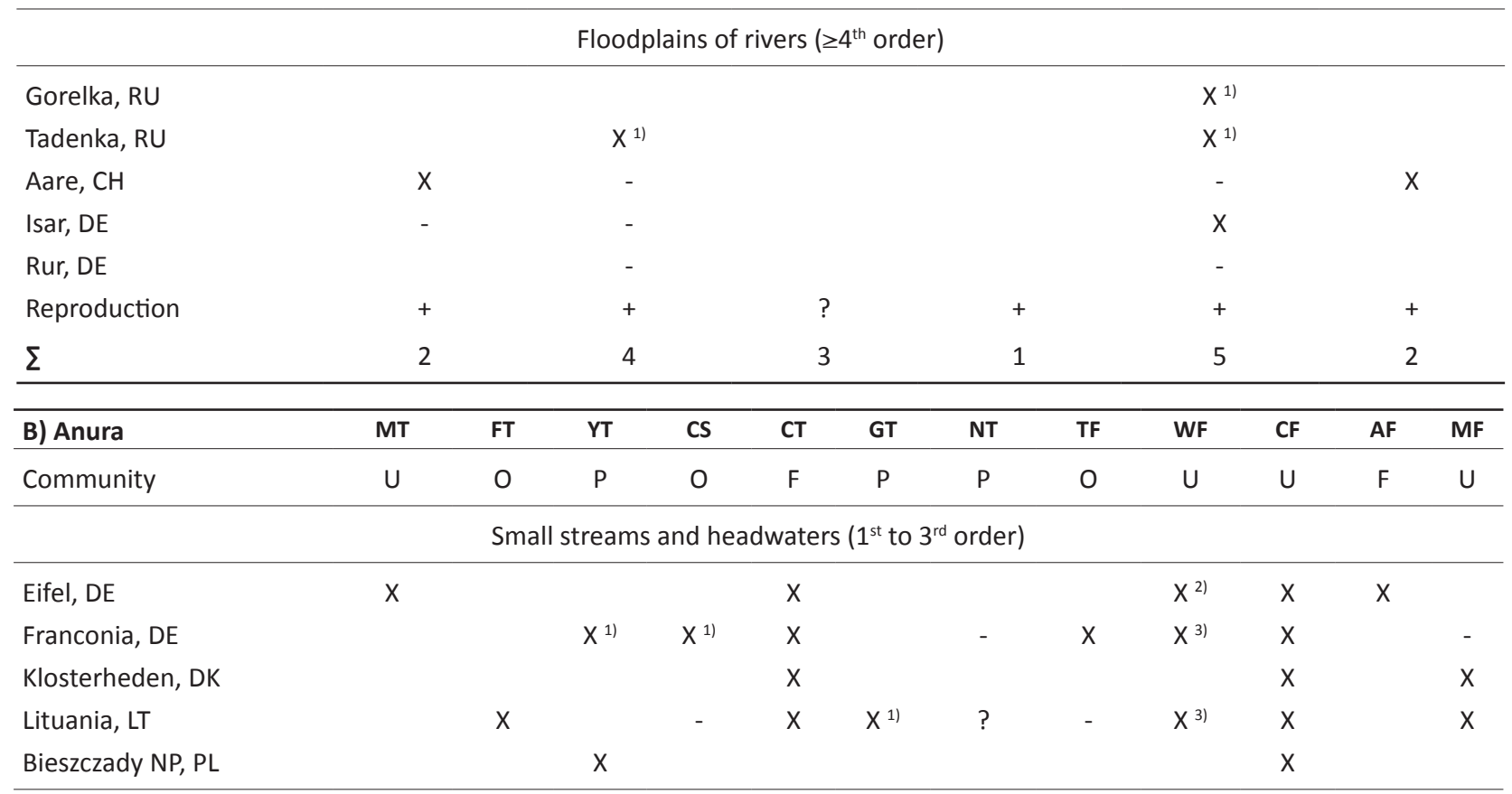

\begin{tabular}{|c|c|c|c|c|c|c|c|c|c|c|c|c|}
\hline \multicolumn{13}{|c|}{ Floodplains of rivers $\left(\geq 4^{\text {th }}\right.$ order $)$} \\
\hline Gorelka, RU & & & & & $x$ & - & & & - & $\mathrm{x}$ & & $x$ \\
\hline Tadenka, RU & & - & & - & $x$ & - & & & $x^{2)}$ & $x$ & & $x$ \\
\hline Aare, $\mathrm{CH}$ & - & & - & & - & & & - & $x^{2)}$ & $x$ & & \\
\hline Isar, DE & & & & & $x$ & & & - & $X^{3)}$ & $x$ & - & \\
\hline Rur, DE & & & & & $x$ & & - & & $X^{31}$ & $\mathrm{X}$ & & \\
\hline Reproduction & + & $?$ & + & - & + & - & - & + & + & + & + & + \\
\hline$\Sigma$ & 1 & 1 & 2 & 1 & 8 & 1 & $0^{5)}$ & 1 & 7 & 10 & $1^{4)}$ & 4 \\
\hline
\end{tabular}

${ }^{1)}$ : single specimens, probably no breeding; ${ }^{2)}$ : P. lessonae / "esculentus ${ }^{\prime \prime}$ complex; ${ }^{3)}$ : including P. ridibundus; ${ }^{4)}$ in SE-Poland common in beaver ponds, breeding recorded (Bonk et al., 2012); ${ }^{5}$ single individuals in beaver ponds in Switzerland (Gschwend, 2015), presence of reproduction not specified.

Table 3). Reproduction was documented for 13 species (eight anuran, five urodelan species) in at least one study. Species richness was highest in the small, 1st to 3rd order streams (Table 2) with up to eight species living in a single beaver pond (Eifel region, DE).

The presence of particular species of amphibian was primarily dependent on distribution patterns. Several species with broad distributions were detected most constantly in beaver ponds; common frog and common toad were among the most frequent species in beaver ponds across nearly all the regions considered (Table 3). Water frogs were widely distributed as well. Four out of seven study areas with records of water frogs supported marsh frogs, in three cases, the pool frog, 
including P. "esculentus", was present. Similarly, the widely distributed smooth newt was the most frequently detected urodelan species (Table 3). Moor frog was a common amphibian species of beaver ponds in the north and east of the area encompassed by the studies; it was found in $>80 \%$ of the studies of beaver ponds within its range (Fig. 2).

On the other hand, the remaining species were rarely found. In the west of the area surveyed, urodelan species that were distributed in central and western Europe, such as the alpine newt but especially the palmate newt, were found regularly in beaver ponds; this was also true for the Carpathian newt in Bieszczady-National Park Poland. The fire salamander was detected in beaver ponds in only two studies. However, all other study areas were outside the range of this species, or the species was generally absent from the larger landscape surrounding the beaver ponds surveyed (e.g. Aare, CH, B. Lüscher, pers. comm.). The European midwife toad was found only in one study area (Eifel, DE) at the western end of the area encompassed by the 10 studies.

Some amphibian species rarely colonise beaver ponds despite their wide distribution such as crested newt, green toad and natterjack toad (Table 3, Fig. 2). The agile frog is rare in the studies reviewed (Table 3 ) but was found reproducing in large numbers in beaver ponds in southern Poland (Bonk et al., 2012).

\section{Amphibian assemblages in beaver ponds}

Species of the four amphibian assemblages were detected with varying regularity among the beaver ponds studied (Table 3, Fig. 2). Ten species were found in $>50 \%$ of the surveys, most of these ( $80 \%$ ) were forest or ubiquitous species (Fig. 2). In contrast, only one of the pioneer species was detected in $>50 \%$ of the studies; the remaining two species occurred in $<10 \%$ of the surveys. Open-country amphibian species showed an intermediate distribution, with two of the five species present in $>50 \%$ of the studies and the remaining found rarely.

\section{Amphibian richness in beaver ponds on different stream sections}

Three out of the five systematic surveys of beaver ponds of small, low-order headwater streams recorded considerable species richness, with eight to nine species (Table 2). Beaver ponds of north-west Denmark were species poor, because these ponds were located in an area without newts ( $\mathrm{M}$. Elmeros, pers. comm.). The beaver sites in Bieszczady-National Park in Poland were colonised by all five species occurring in this rather high elevation area.

The average number of amphibian species in study ponds in a 2 nd order stream in the Eifel region (DE) was considerably higher in beaver ponds, compared to the water bodies in the floodplain which were not occupied by beavers (Table 4); no species were recorded in the stream itself (Dalbeck et al., 2007). The species spectrum of beaver ponds in a second study in this region comprised eight species and corresponded to unused artificial, ponds, which were similar in size and location to the beaver ponds. However, the average number of species in beaver ponds was higher than that of artificial ponds (artificial ponds: 0 to 6 species; Mean: $3.57 \pm 1.33$; $\mathrm{n}=21$, beaver ponds: 3 to 7 species; mean $4.82 \pm 1.18$; $n$ = 22; Dalbeck \& Weinberg, 2009).

In Bieszczady-National Park (PL), the average number of amphibian species at six sites was $1.5( \pm 0.76)$ before and $3.8( \pm 0.68)$ after the colonisation and impoundment of these mountainous headwater streams by beavers. In addition, the absolute number of amphibian species increased from four before to five after beaver colonisation of these sites (Derwich et al., 2007).

In contrast, only one to four amphibian species were observed in beaver ponds in the floodplains of larger rivers $\geq 4$ th order (Aare $[\mathrm{CH}]$, Isar and Rur [DE], Tadenka and Gorelka [RU]; Table 2; 3), including studies using funnel traps (Aare, Isar, Rur). On average, there was only one species per beaver pond (Table 2). Beaver ponds of small headwater streams supported $90 \%$ or more of the regional species pool, whereas many species were missing in beaver ponds in floodplains of larger rivers, with only $\sim 50 \%$ of the species available in the regional pool being detected in beaver ponds (Table 2).

\section{Amphibian abundance}

Only a few studies on amphibian abundance associated with beaver ponds exist. They show that common frog (and moor frog) can establish high densities in northern, central and eastern European beaver ponds, which can contain $80 \%$ to $90 \%$ of the common frog spawn of all waters in a landscape (Dalbeck et al., 2014; Elmeros et al., 2007) or produce a density of common and moor frog metamorphs 10 times higher than that of waters not originating from beavers (Bashinskiy, 2014).

Newts reached densities between 0 and $>2000$ individuals in 22 beaver ponds after a catch-recatch study in the Eifel region with an average of 267 alpine newts and 816 palmate newts per beaver pond (Dalbeck \& Weinberg, 2009). The colonisation by fish had a significant influence on the newt densities. Additionally, alpine and palmate newts together reached densities of $>22000$ individuals in 10 of the 23 beaver ponds investigated in one beaver settlement in this area (Dalbeck \& Weinberg, 2009b).

In contrast, the settlement densities of the common frog in beaver ponds of the Isar floodplains (Bavaria, Germany) were significantly lower than those of other waters in the same area. Furthermore, newts were rarely found in the beaver ponds, and with only few individuals (Junginger, 1997).

\section{DISCUSSION}

The number and distribution of the studies (Fig. 1) reviewed allows a first assessment of the importance of beaver ponds as habitat for amphibian species and assemblages of temperate to boreal central and eastern Europe. As the studies were equally distributed across small headwater streams, larger rivers and their floodplains (Table 2), a first comparison of amphibian assemblages in these two differing stream types is also feasible. 
Table 4. Proportion of waters inhabited by amphibians in 20 beaver ponds and in 11 floodplain ponds in a 2 nd order stream in the Hürtgenwald, Eifel area, Germany (Dalbeck et al., 2007). Preference insolation: Regional preference of insolation of the reproductive waters (following Weddeling \& Willigalla, 2011): ++: requires fully sunlit waters, +: prefers sunlit waters, 0: no preference concerning insolation, -: prefers shady waters, - -: requires fully shaded waters; *: species requires sun-exposed terrestrial habitats. ${ }^{\text {a) }}$ average number of amphibian species \pm standard deviation

\begin{tabular}{lccc}
\hline Species & Floodplain ponds & beaver ponds & preference insolation \\
\hline Water frog (P. lessonae /"esculentus") & $0.0 \%$ & $10.0 \%$ & ++ \\
Smooth newt & $0.0 \%$ & $10.0 \%$ & $+^{*}$ \\
Midwife toad & $0.0 \%$ & $60.0 \%$ & $0^{*}$ \\
Common toad & $0.0 \%$ & $55.0 \%$ & 0 \\
Palmate newt & $18.2 \%$ & $95.0 \%$ & - \\
Common frog & $18.2 \%$ & $65.0 \%$ & - \\
Alpine newt & $36.4 \%$ & $85.0 \%$ & -- \\
Fire salamander & $36.4 \%$ & $35.0 \%$ & \\
\hline Average no. species ${ }^{2)}$ & $1.2 \pm 1.3$ & $4.1 \pm 1.4$ & \\
\hline
\end{tabular}

\section{Amphibian species and assemblages in beaver ponds}

All 19 amphibian species occurring within the geographic area considered (Gasc et al., 2004) were detected in beaver ponds in at least one of the studies, which is noteworthy given the substantial differences in the habitat requirements for breeding, as well as for terrestrial activity. However, species occurred in beaver ponds with varying degrees of regularity (Fig. 2) which appears to be linked to their habitat preferences.

The result confirms the assumption that forest species benefit more clearly from beaver ponds than open land species, especially those that depend on open terrestrial habitats with bare substrate. Typical forest species, like common toad, fire salamander, palmate newt and alpine newt, were present in $80-100 \%$ of studies conducted within their distributional range (Fig. 2). These species can obviously successfully colonise and reproduce in beaver ponds. Besides the forest species, ubiquitous species like water frogs (Pelophylax spp.) and (in the north and east) moor frog were present in almost all of the studies. All of these species are widespread within their ranges including in wooded areas where the beaver prefers to live. Due to their general habitat requirements and wide distributions, they are able to colonise beaver ponds readily and, therefore, are the "backbone" of many amphibian assemblages in beaver ponds in boreal and central-temperate Europe (Table 3).

In contrast, amphibians considered to be pioneer species, in particular green and natterjack toads were particularly clearly underrepresented (Table 3, Fig. 2). For both species, proof of reproduction in beaver ponds is lacking. These species are typical of highly dynamic habitats, like floodplains of gravel-bed rivers with high amounts of physical disturbance, such as Tagliamento (Tockner et al., 2006) and Isar (Kuhn, 2001). The types of open areas created by beaver foraging activities (Naiman et al., 1988) tend not to meet the habitat requirements of these pioneering species. Due to their position in the main channel, beaver ponds are often quickly colonised by predators such as fish (Hägglund \& Sjöberg, 1999). Therefore, the suitability of beaver ponds and surrounding open areas created by beaver for green and natterjack toads is questionable.

Yellow-bellied toads require young, vegetation-free ponds that are often ephemeral for reproduction, but unlike natterjack and green toads, they are not dependent on terrestrial habitats with sparse or no vegetation. This species can even use wild boar (Sus scrofa) wallows as breeding sites (Gollmann \& Gollmann, 2002). Therefore, at least some beaver ponds provide suitable habitat for this species which is highly endangered in many countries (European Union Habitats Directive Annex II and IV). Unfortunately, the reproductive status of this species was not really clear for most of the studies.

On the other hand, fire-bellied toad and smooth newt require breeding waters exposed to high levels of sunlight with high water temperature and, in the case of smooth newt, open terrestrial habitats (Table 4). Unlike the pioneering species, these species do not depend on terrestrial habitats with little vegetation and bare substrate (Nöllert \& Nöllert, 1992). Habitat requirements for the breeding and terrestrial activities of these two species, are generally associated with later successional stages of beaver ponds surrounded by beaver-created clearings.

The midwife toad only occurs in the low mountain ranges in the west of the study area and has relatively specific terrestrial habitat requirements, including sunlit slopes with bare ground in close vicinity to breeding ponds (Nöllert \& Nöllert, 1992). Beaver ponds can have large populations of midwife toad, e.g. in the Eifel (DE) but the species is absent in other localities (Fig. 2). Factors affecting successful colonisation of beaver ponds by the midwife toad remain unknown.

The highly dynamic nature of beaver ponds appears to be a substantial factor in amphibian utilisation. Beaver ponds can persist for 20 or more years. Though many ponds are abandoned after two or three years as reported from Lithuania (Bluzma, 2003) and the Eifel area (Dalbeck et al., 2014). Therefore, amphibian species that require older breeding ponds and open terrestrial habitats are only able to colonise a subset of the beaver ponds available. This is evident as species like tree frog, midwife toad and common newt are reported in only $30 \%$ 
to $70 \%$ of the studies (Fig. 2). As a steppe species, the common spadefoot may rarely inhabit beaver ponds due to the predominance of woody plants and forests.

A factor that should not be underestimated, however, is the threatened status of many amphibian species in Europe. Many species are now missing over large areas of their historical ranges. It can therefore be assumed, that some species were absent from surveys because they cannot reach newly created beaver ponds because they exist in such small and isolated populations.

\section{Beaver ponds of different stream sections}

Amphibian species richness in beaver-impounded small headwater streams, 1st to 3rd order, was high, not only with regard to the absolute and average number of species occurring, but also compared to richness in beaver ponds of larger rivers, $\geq 4$ th order, and their floodplains (Tables $2 \& 3$ ). The nature of the river sections investigated by a study seems to be the main factor in determining the number of amphibian species occupying beaver ponds. Beaver ponds of headwater streams represent most, or even all, amphibian species found in the surrounding landscape. In contrast, in larger river valleys, only half of the amphibian species living in a local area were represented in beaver ponds (Tables 2 \& 3). In addition, the mean number of species per beaver pond was low in these streams (Table 2).

In larger gravel-bed and lowland rivers, floods are the primary physical disturbance leading to the high structural diversity and environmental gradients which are fundamental for the occurrence of high amphibian species richness (Indermaur et al., 2010). Therefore, beaver-created features, such as ponds and clearings, do not add fundamentally new elements to the existing gradient of aquatic and terrestrial habitats.

In small headwater streams, extraordinary flood events can actually create lower levels of disturbance (Dalbeck \& Weinberg, 2009) and therefore environmental conditions are much more homogenous. Beavers are their main source of disturbance and increase both the number and diversity of lentic water bodies on a landscape scale, where beaver ponds can account for up to $96 \%$ of all lentic water bodies observed (Stevens et al., 2007). As 18 of the 19 amphibian species present in central and boreal Europe depend on lentic breeding waters, this effect of beaver activity is responsible for the observed increase in species numbers in small headwater streams. Additionally, by felling and drowning trees, beavers create sunlit corridors (Cunningham et al., 2007) in the naturally forested landscapes which is a prerequisite for open country amphibians. Furthermore, they increase the range of microclimatic conditions (Skelly \& Freidenburg, 2000) enabling amphibian species not typically found in forests to colonise beaver ponds in forested areas (Table 4).

Fish can influence amphibian assemblages in beaver ponds. The presence of fish in beaver ponds of the headwater streams in a German low mountain range (Eifel) influenced the colonisation, density and composition of newt populations (Dalbeck \& Weinberg, 2009). The effect was more pronounced in artificial compared to beaver ponds. Beaver ponds are regularly colonised by amphibian species, such as the moor frog, the midwife toad and fire salamander. These species can occur in large population densities (Dalbeck et al., 2007) though are considered to be particularly sensitive to the presence of fish in their reproduction waters (Weddeling \& Willigalla, 2011). However, the influence of the species composition of fish communities, their settlement density and size distribution on amphibians in beaver ponds remains largely unknown. In particular, the question remains as to what role fish predation plays in the low number of amphibian species in the floodplain beaver ponds of lowland rivers (Table 2) in which fish species communities in Europe are fundamentally different from those in the (central) mountains (Melcher et al., 2007).

\section{Small headwater streams - a species-poor amphibian habitat?}

Studies in the remaining larger lowland and pre-alpine gravel-bed rivers of central Europe have illustrated their high importance for amphibian species richness, not only for large lowland river valleys such as the Rhone or Danube, but for disturbance-dominated gravel-bed rivers (Tockner et al., 2006; Kuhn, 2001; Landmann \& Böhm, 2001). Thus, these floodplain rivers have been recognised as focal areas for amphibian conservation in Europe (Tockner et al., 2006).

Our review demonstrates that beaver-impounded head water streams of central and eastern Europe are inhabited by seven to nine species per site (Table 2) which is higher than those lacking beavers (Günther, 1996; Thiesmeier, 2004; Weddeling \& Willigalla, 2011, Table 4). Species numbers of beaver-shaped headwater streams easily equal those of (semi-)natural pre-alpine gravel bed rivers that are viewed as having high amphibian conservation value, i.e. Isar, Germany: 4 (to 5 ) species (Kuhn, 2001); Lech, Germany: 7 (to 8) species (Landmann \& Böhm, 2001); Tagliamento, Italy: up to 9 species; Aare, Switzerland: 10 species (Lüscher \& Grossenbacher, 2001). This is also applicable to near-natural floodplains of the largest European lowland rivers, such as the central Danube, Austria (10 species, Pintar \& Straka, 1990) or upper Rhone, France (9 species, Morand \& Joly, 1995). Artificial ponds, that resemble beaver ponds in location and amphibian species composition, do not come close to actual beaver ponds in terms of amphibian species number and or densities (Dalbeck et al., 2014). However, it should be noted that the importance of artificial waters for amphibian conservation is often underestimated (Dalbeck \& Weinberg, 2009).

Based on these patterns, we propose that European river systems under natural conditions, have a high amphibian species richness along their entire course from headwater streams to large lowland rivers. The impact of beaver dams on the amphibian species inhabiting rivers in south-western and southern Europe is unfortunately not yet known. Investigations from these regions, which have so far been scarcely repopulated by beavers are lacking. 


\section{Amphibian abundance}

The few available results do not permit a detailed evaluation but outline that the abundance of both anurans and urodelans can increase considerably under the influence of beaver at least in headwater streams. However, this may not apply to every case, e.g. for beaver ponds in the floodplains of larger rivers or for every species equally.

\section{CONCLUSIONS}

The influence of beavers can be extensive, even in central European landscapes, which are densely populated and substantially altered by humans, like the Eifel, Germany (on average 3.9 beaver ponds per $\mathrm{km}$ of stream, Dalbeck et al., 2014) and in Lithuanian lowland forests ( 1.2 beaver ponds per $\mathrm{km}$ of stream, Ulevičius et al., 2009). The influence of beavers on streams, wetlands and groundwater levels in large remote areas of North America is known to be much more extensive (Hood \& Bayley, 2008; Naiman et al., 1988). Since all 19 amphibian species of central and northern Europe are known to colonise beaver ponds, it is clear that beavercreated landscapes may represent, both qualitatively and quantitatively, one of the most important amphibian habitats in northern and temperate Europe.

Multiple threats to Europe's amphibians exist, including diseases such as chytrid fungi $B d$, and currently Bsal (Yap et al., 2017); invasive predators; and pollution including the effects of greenhouse gases (Temple \& Cox 2009). However, the most significant threat remains to be habitat loss, which the beaver has considerable potential to counter. This could particularly apply to endangered species. The majority of the 12 endangered amphibians in the study region listed in Annexes II \& IV of the Habitats Directive are open country species. In these landscapes, the destruction of spawning waters and fragmentation of habitats especially through agricultural intensification is particularly pronounced. If permitted, beavers and their activities increase suitable spawning habitats along forested waters in open country for endangered and characteristic species such as crested newt, fire bellied toad and tree frog. They are able to colonise the forests via sunlit corridors along the streams created by beavers and find suitable habitats there. This also applies to species with specific habitat requirements, such as the midwife toad. Thus, beavers increase habitat availability, reduce habitat fragmentation and increase the area that can be colonised by endangered open land species. The endangered species of the gravel bed rivers green toad and natterjack toad appear less likely to benefit from beavers.

Within the European Union, the European WFD requires member states to achieve good ecological status for all waters, with only slight allowances of declines in biological communities that are expected in conditions of minimal anthropogenic impact (Törnblom et al., 2011). Based on the findings of our review, we propose that: (1) beavers are a pivotal force in potentially shaping natural streams and floodplains of the majority of the watersheds in temperate Europe, (2) the majority of amphibian species should be considered integral parts of the vertebrate assemblages of flowing waters not only in large rivers, but particularly in small streams, (3) and the potential role of beavers in amphibian conservation in Europe is difficult to overestimate. By creating habitat for endangered amphibian species, beavers help to achieve the objectives of the European Habitats Directive, as amphibians are still threatened predominantly by habitat loss, especially of aquatic habitats (e.g. Semlitsch, 2002; Wake \& Vredenburg, 2008). Thus, beavers and their ability to modify habitats offer extensive opportunities to implement many aspects of the WFD, re-naturalise water courses across Europe, and restore amphibian habitats, aiding in their long-term conservation.

\section{ACKNOWLEDGEMENTS}

We would like to thank Karl-Andreas Nische and Volker Zahner for their help with literature searches, Sarah Althaus, Morten Elmeros and Beatrice Lüscher for providing their unpublished reports, and Ivan Bashinskiy, Rémi Duguet, Kurt Grossenbacher, Magdalena Hędrzak and Mia Vehkaoja for willingly answering our questions. Many thanks to Klaus Weddeling for help creating the figures included and finally to Kelsey Wilson in reading earlier drafts for this manuscript.

\section{REFERENCES}

Balčiauskas, L., Balčiauskienë, L. \& Trakimas, G. (2001). Beaver influence on amphibian breeding in the agrolandscape. Proceedings of 2nd European Beaver Symposium 27-30 September 2000 Bielowieza, Poland, pp. 105-112.

Bashinskiy, I.V. (2008). The effect of beaver (Castor fiber Linnaeus, 1758) activity on amphibian reproduction. Inland Water Biology 1, 326-331.

Bashinskiy, I.V. (2012). The main factors of beaver's impact on amphibians in small river valleys. Book of Abstracts, 6th International Beaver Symposium, Ivanič-Grad, Kroatien 17 - 20 Sept. 2012, 47.

Bashinskiy, I.V. (2014). Impact assessment of European beaver reintroduction on amphibians of small rivers. Russian Journal of Biological Invasions 5, 134-145.

Benda, L., Hassan, M.A., Church, M. \& May, C.L. (2005). Geomorphology of steepland headwaters. The transition from hillslopes to channels. Journal of the American Water Resources Association 41, 835-851.

Bluzma, P. (2003). Beaver abundance and beaver site use in a hilly landscape (eastern Lithuania). Acta Zoologica Lituanica 13, 8-14.

Bonk, M., Bury, S., Hofman, S., Szymura, J.M. \& Pabijan, M. (2012). A reassessment of the northeastern distribution of Rana dalmatina (Bonaparte, 1840). Herpetology Notes 5 , 345-354.

Borgula, A. \& Zumbach, S. (2003). Verbreitung und Gefährdung der Geburtshelferkröte (Alytes obstetricans) in der Schweiz. Zeitschrift für Feldherpetologie 10, 11-16.

Bronmark, C. \& Edenhamn, P. (1994). Does the Presence of Fish Affect the Distribution of Tree Frogs (Hyla arborea)? Conservation Biology 8, 841-845.

Cunningham, J.M., Calhoun, A.J.K. \& Glanz, W.E. (2007). Pond- 
breeding amphibian species richness and habitat selection in a beaver-modified Landscape. Journal of Wildlife Management 78, 2517-2526.

Dalbeck, L. \& Weinberg, K. (2009). Artificial ponds: a substitute for natural beaver ponds in a central European highland (Eifel, Germany)? Hydrobiologia 630, 49-62.

Dalbeck, L. \& Weinberg, K. (2009b). Kurzfristige Auswirkungen eines Hochwassers auf Amphibiengemeinschaften in Biberteichen eines Mittelgebirgstales. Zeitschrift für Feldherpetologie 16, 103-114.

Dalbeck, L., Janssen, J. \& Völsgen, S.L. (2014). Beavers (Castor fiber) increase habitat availability, heterogeneity and connectivity for common frogs (Rana temporaria). Amphibia-Reptilia 35, 321-329.

Dalbeck, L., Lüscher, B. \& Ohlhoff, D. (2007). Beaver ponds as habitat of amphibian communities in a central European highland. Amphibia-Reptilia 28, 493-501.

Damm, N. (2009). Effekter af bævere på padder i Klosterheden. Report Amphi Consult, Dänemark, 1-14 (unpublished).

Denoël, M. \& Ficetola, G.F. (2008). Conservation of newt guilds in an agricultural landscape of Belgium: the importance of aquatic and terrestrial landscapes. Aquatic Conservation. Marine and Freshwater Ecosystems 18, 714728.

Derwich, A., Brzuski, P \& Hędrzak, M. (2007). Bóbr w biotopach Bieszzcadów Wysokich. Wydawnictwo DRUKOPL, Kraków, $1-112$.

Elmeros, M., Berthelsen, J.P., Hald, A.B., Andersen, P.N., $\emptyset$ verland, L.K. \& Therkildsen, O.R. (2007). Overvågning af bæver Castor fiber i Danmark i 2007. Danmarks Miljøundersøgelser Aarhus Universitet, Arbejdsrapport fra DMU 247, 1-82.

Elmeros, M., Berthelsen, J.P., Hald, A. B., Andersen, P. N., $\varnothing$ verland, L. K. \& Therkildsen, O.R. (2009). Overvågning af bæver Castor fiber i Danmark i 2007. Arbejdsrapport fra Danmarks Miljøundersøgelser 247, 1-82.

Elmeros, M., Madsen, A.B. \& Berthelsen, P. (2003). Monitoring of reintroduced Beavers (Castor fiber) in Denmark. Lutra 46, 153-162.

Gasc, J.-P., Cabela, A., Crnobrnja-Isailovic, J., Dolmen, D,. Grossenbacher, K., Haffner, P., Lescure, J., Martens, H., Martínez Rica, J.P., Maurin, H., Oliveira, M.E., Sofianidou, T.S., Veith, M., \& Zuiderwijk A. (2004). Atlas of Amphibians and Reptiles in Europe, Second edition. Societas Herpetologica Europeae and Muséum national d’Histoire naturelle, Paris.

Gollmann B. \& Gollmann, G. (2002). Die Gelbbauchunke: von der Suhle zur Radspur. Laurenti Verlag, Bielefeld.

Gschwend, G.P. (2015). Beaver as an ecosystem engineer that creates habitat for amphibians. Institute of Evolutionary Biology and Environmental Sciences University of Zurich, Switzerland (Master Thesis), 1-30.

Günther, R. (1996). Die Amphibien und Reptilien Deutschlands. Gustav Fischer, Jena.

Hachtel, M., Schlüpmann, M., Weddeling, K., Thiesmeier, B., Geiger, A. \& Willigalla, C. (2011). Handbuch der Amphibien und Reptilien Nordrhein-Westfalens, Zeitschrift für Feldherpetologie Supplement 16/1: 1-896.

Hägglund, Å. \& Sjöberg, G. (1999). Effects of beaver dams on the fish fauna of forest streams. Forest Ecology and Management 115, 259-266.
Halley, D. J. \& Lamberg, A. (2001). Populations of juvenile salmon and trout in relation to beaver damming of a spawning stream. In. The European Beaver in a New Millennium. Proceedings of 2nd European Beaver Symposium. Carpathian Heritage Society 122-127.

Halley, D., Rosell, F. \& Saveljev, A. (2012). Population and distribution of Eurasian beaver (Castor fiber). Baltic Forestry 18, 168-175.

Harvolk, S., Symmank, L., Sundermeier, A., Otte, A., \& Donath, T.W. (2014). Can artificial waterways provide a refuge for floodplain biodiversity? A case study from North Western Germany. Ecological Engineering 73, 31-44.

Hecnar, S.J \& M'Closkey, R.T. (1997). The effects of predatory fish on amphibian species richness and distribution. Biological Conservation 79, 123-131.

Hood, G.A. \& Bayley, S.E. (2008). Beaver (Castor canadensis) mitigate the effects of climate on the area of open water in boreal wetlands in western Canada. Biological Conservation 141, 556-567.

Indermaur, L., Gehring, M., Wehrle, W., Tockner, K. \& NaefDaenzer, B. (2009). Behavior-Based Scale Definitions for Determining Individual Space Use: Requirements of Two Amphibians. The American Naturalist 173, 60-71.

Indermaur, L., Schaub, M., Jokela, J., Tockner, K., \& Schmidt, B.R. (2010). Differential response to abiotic conditions and predation risk rather than competition avoidance determine breeding site selection by anurans. Ecography 33, 887-895.

Janiszewski, P., Hanzal, V., \& Misiukiewicz, A. (2014). The Eurasian beaver (Castor fiber) as a keystone species - a literature review. Baltic Forestry 20, 277-286.

Junginger, M. (1997). Die Amphibienvorkommen in den vom Biber beeinflussten Gewässern zwischen Freising und Moosburg. Diplomarbeit der Ludwig-MaximilianUniversität München, Forstwissenschaftliche Fakultät: 1-61 (unpublished).

Keast, A. \& Fox, M.G. (1990). Fish community structure, spatial distribution and feeding ecology in a beaver pond. Environmental Biology of Fishes 27, 201-214.

Klaus, I., Baumgartner, C. \& Tockner, K. (2001). Die Wildflusslandschaft des Tagliamento (Italien, Friaul) und ihre artenreiche Amphibiengesellschaft. Zeitschrift für Feldherpetologie 8 21-30.

Kuhn, J. (2001). Amphibien in der Wildflusslandschaft der oberen Isar (Bayern): Auswirkungen der „Teilrückverlegung“ seit 1990 und des Spitzenhochwassers 1999. Zeitschrift für Feldherpetologie 8, 43-56.

Kuhn, J., Laufer, H. \& Pintar, M. (2001). Amphibien in Flussauen Mitteleuropas: Ein Vorwort. Zeitschrift für Feldherpetologie 8, 3-4.

Landmann, A. \& Böhm, C. (2001). Amphibien in Gebirgsauen: Artenbestand Laichplatzangebot und Laichplatznutzung durch Grasfrosch (Rana temporaria) und Erdkröte (Bufo bufo) in den Auen des Tiroler Lech. Zeitschrift für Feldherpetologie 8, 57-70.

Leu, T., Lüscher, B., Zumbach, S. \& Schmidt B.R. (2009). Small fish (Leucaspius delineatus) that are often released into garden ponds and amphibian breeding sites prey on eggs and tadpoles of the common frog (Rana temporaria). Amphibia-Reptilia 30, 290-293.

Lüscher, B. \& Grossenbacher, K. (2001). Auswirkungen der 
Renaturierung und des Hochwassers 1999 auf die Amphibien-Populationen in der Märchligenau bei Bern. Zeitschrift für Feldherpetologie 8, 97-103.

Lüscher, B. \& Rutishauser, M. (2012). Piloterfassung Amphibien in Belp und Wichtrach 2012. karch Bern, 1-2 (unpublished).

Meßlinger, U. (2012). Monitoring von Biberrevieren in Westmittelfranken. Bund Naturschutz in Bayern e. V., 1-105 (unpublished).

Melcher, A., Schmutz, S., Haidvogl, G. \& Moder, K. (2007). Spatially based methods to assess the ecological status of European fish assemblage types. Fisheries Management and Ecology 14, 453-463.

Metts, B.S., Danham, J.D \& Russell, K.R. (2001). Evaluation of Herpetofaunal communities on upland streams and beaver impounded streams in the Upper Piedmont of South Carolina. American Midland Naturalist 145, 54-65.

Morand, A. \& Joly, P. (1995). Habitat variability and space utilisation by the amphibian communities of the UpperRhone floodplain. Hydrobiologia 300-301, 249-257.

Naiman, R.J., \& Decamps, H. (1997). The ecology of interfaces: riparian zones. Annual review of Ecology and Systematics 28, 621-658.

Naiman, R.J., Johnston, C.A. \& Kelley, J.C. (1988). Alteration of North American streams by beaver. BioScience 38, 753762.

Naiman, R.J., Melillo, J.M. \& Hobbie, J.E. (1986). Ecosystem alteration of boreal forest streams by beaver (Castor canadensis). Ecology 67, 1254-1269.

Nöllert, A. \& Nöllert, C. (1992). Die Amphibien Europas. FrankhKosmos, Stuttgart.

Petranka, J.W. (1998). Salamanders of the United States and Canada. Smithsonian Institution Press, Washington D.C.

Pintar, M. \& Straka, U. (1990). Beitrag zur Kenntnis der Amphibienfauna der Donau-Auen im Tullner Feld und Wiener Becken. Verhandlungen der Zoologisch-Botanischen Gesellschaft in Österreich 127, 123-146.

Pinto, B., Santos, M. J. \& Rosell, F. (2009). Habitat selection of the Eurasian beaver (Castor fiber) near its carrying capacity: an example from Norway. Canadian Journal of Zoology 87, 317-325.

Pintar, M. (2001). Die Amphibien der österreichischen Donauauen. Zeitschrift für Feldherpetologie 8, 147-156.

Ray, A.M., Rebertus, A.J. \& Ray, H.L. (2001). Macrophyte succession in Minnesota beaver ponds. Canadian Journal of Botany 79, 487-499.

Rosell, F., Boszér, O., Collen, P. \& Parker, H. (2005). Ecological impact of beavers Castor fiber and Castor canadensis and their ability to modify ecosystems. Mammal Review 35, 248-276.

Semlitsch, R.D. (2002). Critical elements for biologically based recovery plans of aquatic-breeding amphibians. Conservation Biology 16, 619-629.

Sigourney, D. B., Letcher, B. H. \& Cunjak, R. A. (2006). Influence of beaver activity on summer growth and condition of age-2 Atlantic salmon parr. Transactions of the American Fisheries Society 135, 1068-1075.
Skelly, D.K. \& Freidenburg, L.K. (2000). Effects of beaver on the thermal biology of an amphibian. Ecological Letters 3, 483-486.

Spänhoff, B., Dimmer, R., Friese, H., Harnapp, S., Herbst, F. \& Jenemann, K. (2012). Ecological Status of Rivers and Streams in Saxony (Germany) According to the Water Framework Directive and Prospects of Improvement. Water 4, 887904

Stevens, C.E., Paszkowski, C.A., Foote, A.L. (2007). Beaver (Castor canadensis) as a surrogate species for conserving anuran amphibians on boreal streams in Alberta, Canada. Biological Conservation 134, 1-13.

Temple, H.J. \& Cox, N.A. (2009). European red list of amphibians. European Union Publication Office Publ. No. 333.957094 E89: 1-34.

Thiesmeier, B. \& Günther, R. (1996). Feuersalamander Salamandra salamandra (Linnaeus, 1758). In. Günther, R. (ed.). Die Amphibien und Reptilien Deutschlands. Gustav Fischer Verlag, Jena, 82-104.

Thiesmeier, B. (2004). Der Feuersalamander. Laurenti Verlag, Bielefeld.

Tockner, K., Klaus, I., Baumgartner, C. \& Ward, J.V. (2006). Amphibian diversity and nestedness in a dynamic floodplain river (Tagliamento, NE-Italy). Hydrobiologia 565, 121-133.

Törnblom, J., Angelstam, P., Hartman, G., Henrikson, L. \& Sjöberg, G. (2011). Toward a research agenda for water policy implementation: knowledge about beaver (Castor fiber) as a tool for water management with a catchment perspective. Baltic Forestry 17, 154-161.

Ulevičius, A., Jasiulionisa, M., Jakštienèa, N. \& Žilys, V. (2009). Morphological alteration of land reclamation canals by beavers (Castor fiber) in Lithuania. Estonian Journal of Ecology 58, 126-140. Ulevičius, A., Kisielytè, N. \& Jasiulionis, M. (2011). Habitat use and selectivity by beavers (Castor fiber) in anthropogenic landscape. Ekologija 57, 47-54.

Vehkaoja, M. \& Nummi, P. (2015). Beaver facilitation in the conservation of boreal anuran communities. Herpetozooa 28, 75-87.

Wake, D.B. \& Vredenburg, V.T. (2008). Are we in the midst of the sixth mass extinction? A view from the world of amphibians. Proceedings of the National Academy of Sciences of the USA 105, 11466-11473.

Ward, J.V., Tockner, K. \& Schiemer, F. (1999). Biodiversity of floodplain river ecosystems: Ecotones and connectivity. River Research and Applications 15, 125-139.

Weddeling, K. \& Willigalla, C. (2011). Artenzahlen, Vergesellschaftung und Einfluss der Landnutzung. $\neg$ In. Hachtel, M. Schlüpmann, M., Weddeling, K., Thiesmeier, B., Geiger, A. \& C. Willigalla (ed.). Handbuch der Amphibien und Reptilien Nordrhein-Westfalens Vol. 1, Laurenti Verlag, 98-117.

Wright, J.P., Jones, C.G., \& Flecker, A.S. (2002). An ecosystem engineer, the beaver, increases species richness at the landscape scale. Oecologia 132, 96-101.

Yap, T.A., Nguyen, N.T., Serr, M., Shepack, A., \& Vredenburg, V.T. (2017). Batrachochytrium salamandrivorans and the risk of a second amphibian pandemic. Ecohealth 14, 851-864.

Accepted: 24 January 2020

\section{Please note that the Supplementary Materials are available via the Herpetological Journal website:} https://thebhs.org/publications/the-herpetological-journal/volume-30-number3-july-2020 